\title{
IDENTIFICATION OF THE REQUIREMENTS OF CUSTOMERS OF THE POSTAL COMPANY ON THE SPATIAL AVAILABILITY OF ACCESS AND CONTACT POINTS OF THE PUBLIC POSTAL NETWORK
}

\author{
Dominika Hoštáková ${ }^{1}$
}

\begin{abstract}
In today's globalized world, in the light of evolving electronic communications and alternative delivery methods, there is a decline in submitted consignments. Despite this fact, postal communications still play a significant role in distribution services. In order try to solve this problem, it is essential to identify the causes and the factors of postal market that affect a decline in submitted consignments. The goal of the article is to identify factors that influence the selection of a particular post office based on the customer requirements. To identify these factors, we conducted primary marketing research. Space availability as a major criterion is used for evaluation of the impact of the development of postal infrastructure on the economic level. Determining the criteria of spatial availability preferred by customers and their subsequent alignment with the statutory requirements can not only lead to an increase in the quality of the universal postal service but also to an increase in demand for postal services at certain post offices.
\end{abstract}

JEL Classification Numbers: L87, M31; DOI: http://dx.doi.org/10.12955/cbup.v6.1154

Keywords: space availability, space availability requirements, marketing research

\section{Introduction}

The main goal of every company producing products or providing services is an effort to lead a given market segment. Nowadays, when it comes to oversaturated markets, the key factor to achieve a successful and sustainable position, is mostly the quality of the product or service, which is decisive. One of the most important quality factors for the sector of services is accessibility. The term accessibility is the most defined term in geographic literature, with different methodological approaches to study it and applications for solving geographic problems. In a simple way, accessibility is defined as the ease of reaching a certain location from other locations using the transportation system (Michniak, 2006). Accessibility as a quality criterion for universal postal service providers is also very closely related to the strategic location of individual branches, providing space, with the task of finding a post office set up that will provide the highest level for as many people as possible in the designated territory with the lowest operating costs (Bezák, 1997). Conditions for accessibility as well as layout or the density of access points and contact points of the public postal network is regulated and defined by Quality Requirements for Universal Service, which according to $\$ 41$ of Act no. 324/2011 Coll. on Postal Services and on the amendment and supplementation of certain laws is determined by the Postal Regulatory Office. These set up requirements for spatial accessibility though may not correspond with the real needs of post office customers who may perceive such accessibility in the space from a different point of view. In order to achieve the satisfaction of both parties, it is necessary to identify the requirements of customers for the accessibility of post offices and to incorporate them into the existing conditions.

\section{Literature review}

Many authors have dealt with the term of accessibility in the past and it is still addressed by many of them nowadays. The very origins of accessibility go back to ancient Rome, where the first maps of the territory were worked out and the concept of availability was perceived as an indication of the mutual distance of two points representing cities, markets, intersections of business routes and so on. Later in the 20th century, indicators started to appear, such as indicators of so-called " accessibility rates used for network analysis. For example, Johnston focuses on determining accessibility rates and their application in the US bus network. As a milestone of wider use of term "accessibility", we consider the Ingram study of 1971 and Hagerrstrand study, who, as one of the first authors, paid more attention to the sociological aspect of accessibility in space and time (Tolmáči, 1998). Various measurement methods and accessibility approaches are contained in works by authors such as Handy and Niemeier (1997). Availability in the field of services, particularly in the postal sector, is mentioned in various works and studies in particular in the context of verifying compliance with the accessibility conditions set out in the above-mentioned Universal Service Quality Requirements. The issue of spatial accessibility of postal services in the network of the operator has been mentioned by, for example,

\footnotetext{
${ }^{1}$ University of Žilina, Faculty of Operation and Economics of Transport and Communications, Univerzitná 8215/1, 01026 Žilina, dominika.hostakova @ fpedas.uniza.sk
} 
Križan (2008). In his studies, he measured the availability of post offices in the city of Bratislava in the public transport network and the pedestrian network using perceptual accessibility rates. We divide the accessibility rates into quantitative and qualitative ones. Quantitative accessibility rates are usually expressed in terms of time, distance in kilometres, or cost in money between the various phenomena upon consideration. Qualitative accessibility rates are characterized by the characteristics of a particular territory, the occurrence of bus stops in the vicinity of the phenomenon researched, the occurrence of administrative facilities, shopping centers, and others. These qualitative accessibility rates often affect the availability of space perceived by customers, who then decide to select a particular business or companies to meet their needs.

To find out the factors influencing customers we use various tools, methods, and functions. One of the most used and most simple features for interpreting the results is marketing research. Marketing research means systematic searching, collecting, processing, analyzing and presenting information that serves to identify and address the different business or organization situations (Kotler, 2007). The marketing research process consists of two phases that are arranged in a logical sequence and both of these phases consist of different consecutive steps. The first phase of the research is the preparatory phase of marketing research, which includes the definition of a research problem, research goals, research assumptions, further orientation analysis of the situation and a research plan (Kozel et al., 2011). The research problem characterizes a complex problem, consisting of several factors, that are defined as research objectives and research assumptions to specify the research objectives. The task of situation analysis is to find out what information is needed and available to address the identified research problem. An important document in the preparatory phase of the research is the plan of the research project, which is the plan for the realization of the research and its subsequent control. The second phase of marketing research is the implementation phase, consisting of data collection, processing and its analysis, visualization and interpretation of the achieved results and finally the presentation of the recommendations (Kumar et al., 2002).

\section{Data and methodology}

The main objective of this paper, which is also a research problem of solved marketing research, is to identify factors of spatial accessibility of the access and contact points of Slovak Post, a. s. affecting the demand for services on certain postal facilities from the customer's point of view. Access points and contact points of the public postal network are not only post offices, but also mailboxes, selfservice facilities, post office employees and other places designed to collect or deliver postal items. For the needs of solved marketing research, we will consider only post offices as postal access points and contact points of the public postal network. Post Office of the universal postal service provider. Following this problem, we set out two basic research objectives:

1. Finding requirements for the spatial accessibility of access and contact points of Slovak Post, a. s. from the perspective of the customer.

2. To check customer satisfaction with the accessibility of contact points of Slovak Post, a. s.

The research objectives set by us serve as a basis for the creation of research assumptions, which we will elaborate and verify later. Research prerequisites for our marketing research are:

- At least $1 / 3$ of respondents will put importance on the location of access and contact points of Slovak Post, a. s. within the city center where a certain branch office is located.

- At least $1 / 3$ of respondents will prefer access and contact points of Slovak Post, a. s. located near major shopping centers.

- More than 1/2 of respondents will prefer access and contact points of Slovak Post, a. s., in close proximity of these there is a stop of urban public transport, a suburban bus or train station.

As part of the second step of the preparation phase, which is an indicative analysis of the situation, we have found from alternative sources (Boldron et al., 2008; Križan and Tolmáči, 2008; Madleňák et al., 2015) that our attention has been paid to various issues, but only partially. None of them was concerned with finding specific criteria for the postal operator's customers for the space availability of Slovak Post offices, a. s.. Therefore, the required information needs to be obtained by primary research. The basic set of our marketing research consists of residents of the Slovak Republic who use the services of Slovak Post, a. s. and are in the age group of 18 years and over. Since it is unrealistic to 
receive a completed questionnaire from all residents of Slovakia, it is necessary to calculate the minimum number of respondents required to obtain research results. Given the fact that the population of the Slovak Republic is more than 100000 (5 427917 as of December 31, 2016) we used the following formula for calculating the minimum sample size of respondents: (Trnka, 2016)

$$
\begin{gathered}
n \geq t_{1-\frac{\alpha}{2}} * \frac{\sigma^{2}}{\Delta^{2}}, \\
\sigma=\sqrt{p *(1-p)}
\end{gathered}
$$

where $\mathrm{n}$ is the minimum number of respondents, $t_{1-\frac{\alpha}{2}}^{2}$ the table value that represents the level of confidence was set at $95 \%$ and tells us the amount of uncertainty we can tolerate. Parameter $\sigma^{2}$ represents the variance calculated from the standard deviation, $\mathrm{p}$ is the basic set variability set to 0.5 , and $\Delta$ represents the maximum allowable error range giving the tolerated error amount that we set to \pm 0.1 (the maximum error range is $10 \%$ ). Based on the calculation, we found that the results obtained by our survey would be representative if we made it on a sample of at least 97 respondents. Quota sampling of research is represented by respondents divided by social class, i.e. out of all customers of Slovak Post a. s. we have entrepreneurs who cover $11 \%$, students $6 \%$, working people in the share of $47 \%$, retirees $28 \%$, unemployed $8 \%$ of all customers of Slovak Post a. s.

The final step in the preparation phase of the research process is a plan containing the particular research specifics listed in the following table.

\begin{tabular}{|l|l|}
\hline Table 1: Marketing research plan \\
\hline $\begin{array}{l}\text { Type of research, types and data } \\
\text { sources }\end{array}$ & $\begin{array}{l}\text { Research is quantitative, and data is collected from primary } \\
\text { sources. }\end{array}$ \\
\hline Collection method & Standardized questioning. \\
\hline Collection technique & $\begin{array}{l}\text { An electronic form of standardized query and a paper form of } \\
\text { query that is subsequently converted into an electronic form. }\end{array}$ \\
\hline Sample size & The minimum number of respondents is 97. \\
\hline Method of data analysis & $\begin{array}{l}\text { Statistical methods of marketing research. } \\
\text { Realization and processing of the data obtained is carried out by } \\
\text { the author of the article. }\end{array}$ \\
\hline Role of researchers & $\begin{array}{l}\text { The survey was carried out in the period from } 09.10 .2017 \text { to } \\
01.12 .2017 .\end{array}$ \\
\hline Schedule of the survey & Questionnaire pre-test on a sample of 10 respondents. \\
\hline A method of questionnaire testing & \\
\hline Source: Author &
\end{tabular}

\section{Results and Discussion}

Primary data collection and the process of questioning were done using a Google Docs e-questionnaire and printed questionnaire. Electronic questionnaires were distributed to respondents via the Internet. Filled in questionnaires in printed form were converted into electronic form for their faster and more transparent processing. The form of the questionnaire consisted of several parts. The first part was an introduction that was used to inform respondents about the researched topic and providing instructions how to fill it in. Further, it also consisted of an identification and information section. The identifying section contained questions to get information about respondents. The informative part included merit questions relating to the research objectives. Last but not least, the questionnaire also included the last part dedicated to say thank you to the respondents who participated in the research and completed a questionnaire. Two types of responses were used in the questionnaire: closed, where an alternative response option was offered and the so-called rating scale that allowed us to find the respondent's opinion on the given question, in other words, the importance of the factor to which the question has been addressed. The questionnaire used had only one limitation on the respondents' age, i.e. the respondents had to be over 18 years of their age.

Processing and data analysis were realized by analysing the numbers and occurrences of the received answers through the percentage calculations (Markechová et al., 2011) for which it was necessary to create additional tables for individual issues. As part of the interpretation of the results, some of the data was transformed into different types of graphs for improved final information, and the 
questioning phase provided the following information. The total sample size is 98 respondents with the prevalence of female representation. In terms of age, the largest group consisted of respondents aged 51 to 68 , and the least respondents were aged 69 and over. Of the total number of respondents, most of the respondents came from the city and the largest part consisted of post-secondary school students. According to the social status of the respondents, the largest number of respondents, namely $44.9 \%$, were respondents which worked, the second largest group was retired people, representing $30.6 \%$ of the total number of respondents, followed by entrepreneurs representing $10.2 \%$, then the unemployed respondents, $2 \%$ and the smallest group, representing $5.1 \%$ were students. Since the distribution of respondents to individual social groups represents a quote from the above we can state that a predetermined percentage representation, except for small differences representing no more than \pm 3 respondents, have been observed. The specific results of questionnaire identification questions characterizing the survey respondents are shown in the following table.

\begin{tabular}{|c|c|c|c|}
\hline Gender of respondents & & $\begin{array}{l}\text { - Man } \\
\text { - W... }\end{array}$ & \\
\hline \multirow{7}{*}{ Age of respondents } & \multirow{2}{*}{ Age category } & \multicolumn{2}{|c|}{ Multiplicity } \\
\hline & & Absolute & Relative \\
\hline & from 18 to 30 years & 16 & $16.3 \%$ \\
\hline & from 31 to 40 years & 16 & $16.3 \%$ \\
\hline & from 41 to 50 years & 24 & $24.5 \%$ \\
\hline & from 51 to 69 years & 30 & $30.6 \%$ \\
\hline & from 69 and more years & 12 & $12.2 \%$ \\
\hline Residence of respondents & & \multicolumn{2}{|c|}{ - City } \\
\hline \multirow{5}{*}{$\begin{array}{l}\text { Educational attainment of } \\
\text { respondents }\end{array}$} & \multirow{2}{*}{ Educational attainment } & \multicolumn{2}{|c|}{ Multiplicity } \\
\hline & & Absolute & Relative \\
\hline & Basic & 7 & $7.1 \%$ \\
\hline & Secondary & 74 & $75.5 \%$ \\
\hline & University & 17 & $17.3 \%$ \\
\hline
\end{tabular}

Source: Author

Another group of primary research questions focused on the frequency of use of postal services, in other words, the frequency of visiting postal access and contact points, and satisfaction with its accessibility. The majority of respondents, i.e. $40.8 \%$ said that postal services are used once a month by them. The second largest group consists of respondents who use postal services once a week. $19.4 \%$ of respondents use postal services several times a week and $7.1 \%$ of respondents less than once a month. In Table no. 3 is clearly visible that only $5.1 \%$ of respondents use postal services every day. One of the setup goals of our research is to define the satisfaction of customers with the accessibility and access points of Slovak Post, a. s.. From the graph in Table 3 that is illustrating this goal, we can conclude that with the distribution and accessibility of postal services, the vast majority of customers of the universal service provider are very satisfied. In particular, $67.3 \%$ of respondents are very satisfied, out of these 27 of them are employed, 21 are retired, 7 are entrepreneurs, 6 are unemployed and 5 are students. Partially satisfied with accessibility are $7.1 \%$ of respondents, with 5 respondents employed and 2 retirees. Completely dissatisfied with the distribution and accessibility of post offices were expressed by only two respondents who are retired.

The main part of the primary research is to find out the requirements for the spatial accessibility of access and contact points of Slovak Post, a. s. from the perspective of the customer. Based on the weightings and respondents' answers to the question concerning what affects customers the most within choosing a specific facility for the required service, we have determined the order of importance of each criterion. 


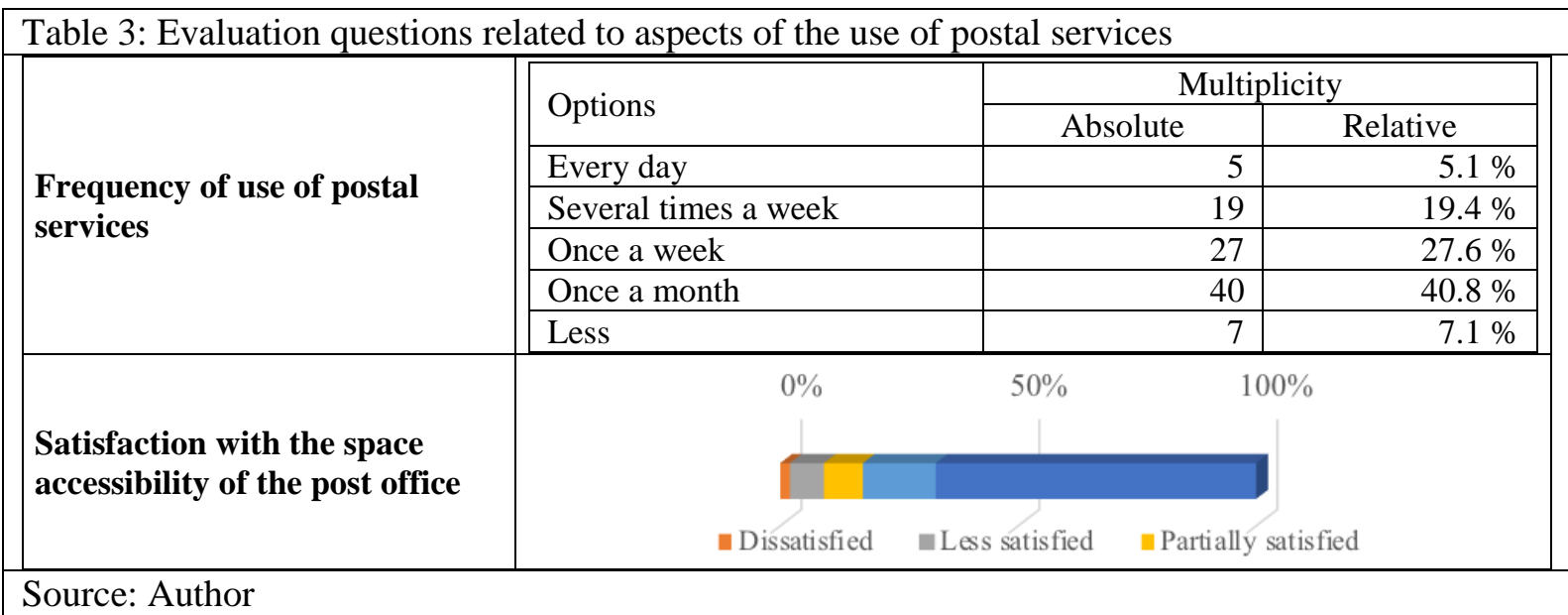

\begin{tabular}{|l|r|r|r|r|}
\hline \multicolumn{2}{|c|}{ Table 4: Determination of the importance of particular spatial availability requirements } \\
\hline Weight allocation & $\mathbf{1}$ & $\mathbf{2}$ & $\mathbf{3}$ & Signification \\
\hline Location of mail (in the city center) & 22 & 26 & 50 & 2.29 \\
\hline $\begin{array}{l}\text { Access to the post office (adjustment of stairs before entering the } \\
\text { post office, barrier-free access) }\end{array}$ & 59 & 15 & 24 & 1.64 \\
\hline $\begin{array}{l}\text { Proximity of stops (urban public transport, suburban bus or train } \\
\text { station) }\end{array}$ & 28 & 31 & 39 & 2.11 \\
\hline $\begin{array}{l}\text { Proximity of parking spaces (at the post office or within one } \\
\text { minute of post office) }\end{array}$ & 64 & 15 & 19 & 1.54 \\
\hline $\begin{array}{l}\text { Civic amenities in the vicinity of the post office (shopping } \\
\text { centers, food and medical facilities, etc.) }\end{array}$ & 53 & 36 & 9 & 1.55 \\
\hline Other & 2 & 0 & 0 & 0.02 \\
\hline Source: Author & & \\
\hline
\end{tabular}

Based on a multi-attribute processes that is created for global opinions (Mateides, 1999), we found out that for customers of Slovak Post, a. s. the criterion of the location of the post office facility is the most important. This means that respondents put the highest importance on the location and access points of Slovak Post, a. s. within the city center where a certain branch of the post office is located. The second most important criterion is that there are stops of urban public transport, a suburban bus or train stations near the post office. On the contrary, if we do not take into account the answer of "others", since only two respondents answered that they considered important something else than offered, but did not give a specific example, then the least important factor for customers is the proximity of parking spaces nearby post office.

After processing and evaluating the results of primary research, we can verify the correctness of the research assumptions (Khusainova et al., 2016) that we have set in the preparatory phase of the marketing research. Out of the total number of respondents asked, $51 \%$ of respondents find the branches of Slovak Post, a. s. that are located in the city center the most important to use, $26.52 \%$ of respondents consider it important and $22.48 \%$ as unimportant. It can be concluded from this that for up to $77.52 \%$ respondents, the location of post offices in the city center is important. Thus, we can state that the research hypothesis that at least $50 \%$ of the respondents will consider the location of access points and contact points of the Slovak Post in a city center to be important, as confirmed. The other hypothesis, we stated was that at least $33 \%$ of respondents will prefer access and contact points of Slovak Post located near major shopping centers. This second assumption has also been confirmed, because $9.18 \%$ of respondents are strongly influenced by the civic amenities which are in close proximity to the post office and $36.73 \%$ of the respondents are affected by these amenities. Based on this we can say that almost up to $45.91 \%$ of respondents prefer post offices that are close to major shopping centers. The last hypothesis in which we state that more than $50 \%$ of respondents will prefer the access points and contact points of Slovak Post, which are close to urban and suburban bus or train stations, has also been confirmed, because a total of $71.43 \%$ interviewees prefer post offices with bus or train stops nearby. 


\section{Conclusion}

The main purpose of this paper was to point out what factors of the spatial availability of access points and contact points of the public postal network affect the customers of the post office while selecting a particular post office. From the primary research, we found out that the post office customers demand that individual postal facilities are allocated in the city center and near urban and suburban bus or train stations. Based on the results of marketing research we recommend reconsidering and aligning the requirements of customers for the availability of access points and contact points of the public postal network to the statutory requirements which can help not only to improve the quality of postal services but also to increase the number of postal operators and improve their possible strategic location. The acquired knowledge from the conducted research serves as a basis for further investigation of the availability of the postal transport network from the perspective of the customer based on the use of methods of the p-median gravitational model.

\section{Acknowledgements}

VEGA 1/0721/18 Research on the Economic Impact of Visual Smog in Transport Using Neuroscience Methods.

\section{References}

Achimský, K. (1988) Simulačné modely vo výuke a ich využitie pri riešení problémov prepravy pošty a PNS. In: Celoštátny vedecký seminár. F-PEDaS VŠDS. Žilina. 115-117.

Bezák, A. (1997). Priestorová organizácia spoločnosti a územno-správne členenie štátu. Acta Universitatis Matthiae Belii. Geografické štúdie, 3, 6-13.

Boldron, F. et al (2008). Accessibility of the postal retail network, social cohesion and economic development. In Crew, M.A., Kleindorfer, P.R. eds. Competition and Regulation in the Postal and Delivery Sector. Edward Elgar Publishing, 47-61, ISBN 1847205070

Khusainova, R. M., Shilova, Z. V., Curteva, O. V. (2016). Selection of appropriate statistical methods for research results processing. In: Mathematics education, 11, 303-315. ISSN 1306-3030.

Kotler, P. (2007). Moderní marketing. Grada Publishing. Praha. 4nd. 1048 s. ISBN 978-80-247-1545-2.

Kozel, R., Mynářová, L., Svobodová, H. (2011). Moderní metódy a techniky marketingového výzkumu. Grada Publishing. Praha. 1nd. 304 s. ISBN 978-80-247-3527-6.

Križan, F., Tolmáči, L. (2008). Meranie priestorovej dostupnosti pôšt na území mesta Bratislava (kvantitatívny prístup). In: Pošta, telekomunikácue a elektronický obchod, 3, 8-16. ISSN 1336-8281.

Križan, F. (2009). Dostupnost' vybraných zariadení služieb na území mesta Bratislava aplikáciou miery založenej na príležitostiach. In: Acta Geographica universitatis comenianae, 53, 149-167.

Kumar, V., AAker David, A., Day George S. (2002). Essentials of marketing research. Wiley, New York. 2nd. 553 s. ISBN 047141235X.

Madleňák, R., Madleňáková, L., Štefunko, J. (2015). The variant approach to the optimization of the postal transportation network in the conditions of the Slovak republic. In: Transport and telecommunication journal, 3, 237-245. ISSN 1407-6160.

Madleňák, R. et al (2016). Multiple approaches of solving allocation problems on postal transportation network in conditions of large countries. In: Transport and telecommunication journal, 3, 222-230. ISSN 1407-6160.

Markechová, D., Tirpáiková, A., Stehlíková, B. (2011). Základy štatistiky pre pedagógov. Fakulta prírodných vied UKF v Nitre. Nitra. 2nd. 405 s. ISBN 978-80-8094.

Mateides, A. (1999). Spokojnost' zákazníka a metódy jej hodnotenia: koncepty a skúsenosti. EPOS. Bratislava. 1nd. $268 \mathrm{~s}$. ISBN 80-8057-133-9.

Michniak, D. (2003a). Dostupnost’ okresných miest na Slovensku. Geografický časopis, 55(1), 9-21. Retrieved from http://akademickyrepozitar.sk/sk/repozitar/dostupnost-okresnych-miest-na-slovensku.pdf.

Michniak, D. (2014b). Vybrané prístupy k hodnoteniu dopravnej dostupnosti vo vzt’ahu k rozvoju cestovného ruchu. Geographical journal, 66(1), 21-38. Retrieved from https://www.sav.sk/journals/uploads/03101206Michniak.pdf.

Poštová licencia (2017). Číslo 145/ORPS/2017-895 z 27.11.2017. Retrieved from https://www.posta.sk/subory/560/postovalicencia-2009.pdf.

Požiadavky na kvalitu univerzálnej poštovej služby (2015). Príloha Poštovej licencie č. 240/001/2012. Retrieved from https://www.posta.sk/subory/561/poziadavky-na-kvalitu-2009.pdf.

Tolmáči, L. (1998). Miery dostupnosti, koncepcia pojmu a teoretická báza. In: Acta Facultatis rerum naturalium Universitatis Comenianae. Slovenské pedagogické nakladatel'stvo. Bratislava. Geographica, 41, 175-191.

Trnka, A. (2016). Základné štatistické metódy marketingového výskumu. In: Fakulta masmediálnej komunikácie. Univerzita sv. Cyrila a Metoda v Trnave. 116 s. ISBN 978-80-8105-768-7.

Zákon č. 324/2011 Z. z. o poštových službách a o zmene a doplnení niektorých zákonov (2011). § 47, odsek 4. Retrieved from https://www.posta.sk/subory/562/zakon-o-postovych-sluzbach.pdf. 